Jozef Tatár

ORCID: 0000-0003-0581-3265

Univerzita Mateja Bela Banská Bystrica, Slovenská republika

\title{
Migrácia v umeleckej literatúre Bariaková Zuzana, Jakubík Henrich, Kubealaková Martina: Hranice okolo nás a v nás: Literárne podoby migrácie $v$ slovenskej literatúre, 2019
}

https://doi.org/10.34739/clit.2021.15.24

Vedecká monografia Hranice okolo nás a v nás: Literárne podoby migrácie $v$ slovenskej literatúre je po monografii Samota a osamelost' (vo vybraných textoch slovenskej umeleckej literatúry, 2013) d'alšou spoločnou knižnou realizáciou trojice autorov z Katedry slovenskej literatúry a literárnej vedy Filozofickej fakulty Univerzity Mateja Bela v Banskej Bystrici. Po nedávno vydanom zborníku Literárne podoby migrácie (2019) ide o druhý publikačný výstup grantového projektu VEGA č. 1/0157/17 s rovnomenným názvom.

Monografia potvrdzuje aktuálnost' zatial' výraznejšie neprebádanej problematiky - témy l’udskej migrácie, emigrácie, pohybu, st’ahovania, ktorá celospoločensky (celosvetovo) zarezonovala ako hromadný jav aj v posledných rokoch 21. storočia. Celá plejáda podôb migrácie v literárnovývinovej perspektíve a v rámci druhovo-žánrovej rozmanitosti diel/textov umožnila autorskému kolektívu využit hlavne vlastný interpretačný potenciál. Na mnohovrstvovosti témy sa podielajú najmä subjekty migrácie, ktoré rámcujú ne/zaujatí cestovatelia (pozorovatelia) a subjekty oscilujúce medzi vlastnou a nadobudnutou identitou. Analyticko-interpretačné (aj komparačné) čítanie cestopisov staršej i novšej proveniencie a súčasných prozaických textov potvrdilo záujem migrantov o nadväzovanie a rozvíjanie medzil'udských vztahov ako obranného mechanizmu na samotu a osamelost' postáv a riešenie dramatických životných situácií v cudzom prostredí. 
Monografii nechýba požadovaná vedeckost', teoreticko-metodologická jednotnost' a vyváženost', kompaktnost'; zároveň je mimoriadne podnetná smerom $\mathrm{k}$ d’alšiemu výskumu danej témy či z nej vyplývajúceho stavu samoty a pocitu osamelosti, prípadne outsiderstva. Hodnotový postoj autorov kjednotlivým textom je závislý hlavne od problémového zmocnenia sa ponúkanej látky. Popri záujme o migráciu v podobe fyzického presunu z miesta na miesto, ked' nový sociálno-prírodný priestor predstavuje pre subjekt užitočnú zónu živého (i konfliktného) kontaktu s „inakostou“, často vystaveného tlaku odlišných kolektívnych predstáv, je adekvátna pozornost’ venovaná aj fenoménu tzv. mentálnej migrácie.

Z publikácie Hranice okolo nás a v nás: Literárne podoby migrácie $v$ slovenskej literatúre vyplýva, že migrácie ako jedného zl’udských existenciálov, literárne reflektovaných od najstarších čias po súčasnost', sa autorky a autor nemohli (ani nechceli) zmocnit’ komplexne. Ich zámerom nebolo vytvorit’ dejiny pohybu, ale, ako je v úvodnej časti uvedené, postihnút’ príčiny a dôsledky migrácie, no najmä jej individuálne prežívanie.

Obsahová štruktúra prezrádza, že trojica autorov ponúka okrem rámcových častí v podstate štyri nosné interpretačné kapitoly. Prvá - Jeden Konštantínopol, a predsa dva - včasovom rozpätí od renesančného humanizmu po osvietenský klasicizmus, je zameraná na cestopisné texty J. Dernschwama, P. Rubigala a J.I. Bajzu. Pre uvedený časový rámec je typický prechod od konkrétnej cestovatel'skej skúsenosti k fikcii, od autorov (Martýri protestantskej viery: D. Krman ml., T. Masník, J. Simonides, J. Láni) k hrdinovi (René). Rôzne formy cestopisného žánru v starších obdobiach vývinu slovenskej literatúry umožňujú interpretovat’ migráciu ako racionálne poznávanie a emocionálne prežívanie (M. Kubealaková).V d’alšej kapitole - od H. Jakubíka - Na ceste do neznáma - je tiež prostredníctvom vhodného výberu diel/textov od literatúry postromantizmu až po realizmus a výstižných interpretácií tematizovania migrácie (napr. vystahovalectvo) mnohými autormi (od Laskomerského - po Timravu) dôraz položený aj na žánrové premeny (cestopisná črta poviedka, novela). Adaptácia expatiek v cudzom prostredí a konfrontácie s ním je náplňou poslednej časti monografie s názvom Niektoré hranice nemôžeš prekročit'. Interpretácia problematizovania novej reality hrdiniek trojice prozaičiek (Dobrakovová, Kepplová a Žuchová) je správne prepojená aj so sociologickým, etickým i psychologickým kontextom (Z. Bariaková). 